\title{
Predictability of Permanence in "Perfect" Library Bindings
}

By LEE E. GROVE

Ce Derfect" (also known as "adhesive" $\mathbf{I}$ or "unsewn") binding was probably invented when some stationer, now lost to memory, applied a flexible glue to the trimmed edge of a stack of paper and created a "pad."

Binders ever since have been attempting to apply "perfect" binding to books. The first notable successes were achieved with telephone directories and mail order catalogs-these were bulky volumes printed on a thin, porous paper, and ... they were not required to last very long.

Then came paper-backs. "Perfect" binding made these possible, because they are most frequently not printed in signatures or gatherings, as are ordinary books, but rather on endless, continuous rolls, which, when cut into pages, present a trimmed edge-just the situation for "perfect" binding. Here, too, was the combination of a porous paper and low requirements for permanence.

But "perfect" binding has progressed still further. Not only are a number of periodicals of national circulation now bound in this manner, but also the books of certain leading publishers. There exist copies of books in trade editions, "perfect" bound, which are still in good condition after fifteen years.

In this situation librarians look hungrily toward "perfect" binding as a method for getting better (i.e. more flexible) binding than the oversewn bindings which they now generally procure, or at less cost than the traditionally sewn bindings which they must buy if they want their books to open flat. But (except in cases where it may be expected that the book can be discarded in five to ten years) the risk of resorting to "per-
Mr. Grove is Director of Publications of the Council on Library Resources, Inc. This report is based on the preliminary investigation by $W$. J. Barrow.

fect" binding is too great. No librarian can face with equanimity the prospect that his books may fall apart before he is ready to discard, and with many books in many libraries this may be twentyfive or fifty years or even a longer time. It is one thing (and we are not sure even how good this is) to employ this fmethod in edition binding, where all the copies are uniform, where the technique can be regulated to the particular paper involved, and where the use is limited to one or at most few readers; it is another to apply it, as in library binding, to a miscellaneity of books which vary in paper content from book to book, or even (as is often the case with periodicals) within the same book, and where the use may run to scores of times.

In other words, before "perfect" binding can be used with confidence for library binding, we need to know more about its performance under varying conditions. How to find out?

The fact is that there is as yet no way of predicting the performance of "perfect" binding adhesives. They are too new to have been able to demonstrate "natural" aging over a period of time which librarians would consider adequate. In the case of paper we have been able to correlate "artificial aging" tests against observed "natural" aging to such a degree that we can use the tests with confidence as predictors of future performance over long periods. With the 
plastic adhesives there is as yet no such correlation. Can we make up for this lack, or must we await the natural evidence of future decades?

To seek an answer to this question, the Council on Library Resources asked William J. Barrow of Richmond, Virginia, well-known for his researches in the permanence of paper, to make a preliminary inquiry to design, if possible, a program of investigation looking to the development of criteria for predicting the performance of "perfect" binding adhesives when used for library binding. In the inquiry, Mr. Barrow associated with himself a group of consultants-Dr. Robert B. Hobbs, chief of the Paper Section of the National Bureau of Standards; Dr. Reavis C. Sproull, paper consultant, and Mr. A. L. Rothschild, chief chemist of the Standard Paper Manufacturing Company, both of Richmond. His report has recently been submitted.

His first step was to procure a literature search, conducted by Dr. Ray $O$. Hummel, assistant librarian of the Virginia State Library. Little was found bearing directly on the problem. (The most useful references are nevertheless listed in the bibliography at the end of this article.)

His second step was to seek test equipment for measuring the performance of adhesives in bound books. There was no such equipment. ${ }^{1} \mathrm{He}$ was compelled to design and construct his own. Although still in a rudimentary form, and though still insufficiently correlated with actual experience, the book-opening device illustrated here roughly performs the operations that a reader does when he sets a book down on its spine and opens it. It was found that the results secured from this apparatus accorded with common experience; books bound with a flexible glue held out longer than when a less flexible glue was employed; books with a

\footnotetext{
1 The tumbling test devised by the US Testing Company is for the overall characteristics of book bindings, not specifically for the performance of the adhesives. Library Journal, LXXXII (1957), 48-49.
}

weak reinforcing paper gave way before those with a stronger paper; thick books broke down earlier than thin ones, etc.

His third step was to perform some simple experiments with adhesives, both old and new, in order to develop experimental techniques and to seek clues to predictability of performance. It was found, for example that the preparation of samples of glue, or the glue-to-water ratio is not critical for $\mathrm{pH}$ (acidity) determinations of this adhesive. It was found, too, that the glues in fifty-yearold books were uniformly acid, that the acid had in most cases migrated to the immediate areas of the attached paper, and this migration materially affected the durability of the binding. Experiments with polyvinyl acetate (much used in "perfect" binding) showed that when soaked in water it first gains, then loses acidity, indicating the release of some volatile substance, and that papers dipped in a PVA solution exhibit similar effects.

Heat-aging tests on glues of "perfect" binding quality showed rapid loss of strength, possibly ascribable to loss of plasticiser or dehydration. (But it was also found that heat-aging at temperatures at $80^{\circ} \mathrm{C}$. or above proved disastrous to the adhesive.) Acidity increased during heat-aging. Heat-aging of paper impregnated with PVA gave preliminary evidence of slight increases in acidity.

From the preliminary inquiry $\mathrm{Mr}$. Barrow and his consultants have concluded that test apparatus can be perfected and that meaningful chemical and other physical tests can be developed which promise valuable information regarding the performance over long periods of time for adhesives used in bookbindings. He believes that, although the long-term performance of adhesives. cannot now be predicted with any confidence, yet that there is good possibility that application of available experimental methods may materially extend such predictability.

COLLEGE AND RESEARCH LIBRARIES 


\section{Bibliography}

1. "Adhesives in the Paper Industry," Paper Industry, XXXX-XXXXII (November, 1958-June, 1960):

"Economics and Technical Achievements," XXXX (1958), 515-517.

"The Theory of Adhesion," XXXX (1958), 593-595.

"Classification of Adhesives," XXXX (1959), 673-674.

"Animal-based Adhesives," XXXX (1959), 730-732, 740.

"Casein and Animal Blood Adhesives," XXXX (1959), 808-809, 837.

"Vegetable Base Adhesives-Starch and Dextrin Adhesives," XXXXI (1959), 12-14, 24.

"Natural Rubber and Natural Resin Adhesives," XXXXI (1959), 248, 254.

"Gums and Vegetable Protein Adhesives," XXXXI (1959), 89-90, 148.

"Vegetable Base Adhesives-Cellulose Adhesives," XXXXI (1959), 173-174.

"Inorganic Adhesives," XXXXI (1959), 311-312.

"Synthetic Resin Adhesives-Aldehyde Based Resins," XXXXI (1959), 382-383.

"Synthetic Resin Adhesives-Epoxy, Polyurethan and Polyester Resins," XXXXI (1959), 460, 466.

"Synthetic Resin Adhesives-Polyvinyl Alcohol and Polyvinyl Acetate," XXXXI (1959), 545-546.

"Styrene Resins and Synthetic Elastomers," XXXXI (1959), 641, 652.

"Miscellaneous Resin Adhesives," XXXXI (1960), 706, 709.

"Important Adhesive Forms-Remoistenable Adhesives," XXXXI (1960), 781.

"Important Adhesive Forms-Water Dispersed Adhesives, Lacquer and Solvent Activated Adhesives and Pressure-Sensitive Adhesives," XXXXI (1960), 854-855.

"Heat Seal and Hot Melt Adhesives," XXXXII (1960), 23, 32.
"Important Adhesive Forms-Pressure Sensitive Adhesives, The Vinyl Alkyl Ether Polymers," XXXXII (1960), 104, 111.

"Adhesive Applications in the Paper Industry," XXXXII (1960), 178, 180.

2. "Adhesive Testing Methods," TAPPI (Technical Association of the Pulp and Paper Industry), XXXIX (December, 1956), sup 116A-17A.

3. "Binding for Pocket Books, Inc. at J. W. Clement Co.," Publisher's Weekly, CLXXVI (September 7, 1959), 82-4.

4. Brown, Rodney G. "Book-Binding Adhesives and a Method for Applying Same," Chemical Abstracts, XXXXVII (February 25, 1953), 1982b.

5. - "Bookbinding Adhesive and a Method of Applying Same," Official Gazette of the U. S. Patent Office, Serial No. 697, 823, (September, 1952).

6. Carson, F. T. and Weber, C. G. "Performance of the 'Perfect' Book Binding," Library Journal, LXXIII (June 15, 1948), 918-923.

7. "Impact Wear Test for Bookcloths Described in Laboratory Report," Patra News, LXXXXIIII (October, 1953), 12.

8. Library Binding Institute. Library Binding Institute Standard for Library Binding. (3rd ed.) Boston: Library Binding Institute, 1960.

9. - Library Binding Institute Standard for Pre-Library Bound New Books. Boston: Library Binding Institute, 1958.

10. "Paperback Bookbinding at W. F. Hall Printing Co.," Publisher's Weekly, CLXXVI (September 7, 1959), 74-1.

11. Sermattei, J. P. "DuPont Hot Melt Bookbinding Adhesives," Graphic Arts Monthly, XXX (December, 1958), 1016.

12. Smith, F. and Montgomery, R. Chemistry of Plant Gums and Mucilages, New York: Reinhold Publishing Corporation, 1959.

13. Stainsby, G. Gelatin and Glue Research. New York: Pergamon Press, 1958. 
14. U. S. Congress. Joint Committee on Printing. "Machine-Finish End Paper," Proposal for Furnishing Paper for the Public Printing and Binding, Beginning November 1, 1960. Washington, D. C.: Government Printing Office, 1960.

15. U. S. General Services Administration, Federal Supply Service. Federal specification Textile Test Methods, CCC-T19-b Amendment-4, Part-2, October 10, 1957. Washington, D. C.: U. S. Government Printing Office, 1957.

16. U. S. Government Printing Office. "Bindery Glues," GPO-PIA Joint Research Bulletin, B-3, 1947.

17. - "Bookbinding Pastes," GPO-PIA Joint Research Bulletin, B-2, 1947.

18. — . "Miscellaneous Bookbinding Adhesives," GPO-PIA Joint Research Bulletin, B-4, 1954.

19. "Miscellaneous Bookbinding Adhe- sives," GPO-PIA Joint Research Bulletin, B-4, 1953.

20. — : Purchasing Division. Specifications for Furnishing Material for the Government Printing Office for the Six Months Beginning July 1, 1959, Washington, D. C.: U. S. Government Printing Office, 1959.

21. U. S. National Bureau of Standards. Book Cloths, Buckrams, and Impregnated Fabrics for Bookbinding Purposes except Library Bindings, Commercial Standard CS57-40, (2d ed.) Washington, D. C.: U. S. Government Printing Office, 1940.

22. U. S. Testing Co. Tests and Procedures for Books and Book Components, Hoboken, N. J.: United States Testing Co., [195?].

23. Upton, P. B. G. "A Technologist Looks at Books," Printing Technology, III (January, 1960).

\section{ACRL Hospitality Booth}

A special feature of ACRL's activities at the Cleveland Conference of ALA was a hospitality booth in the professional exhibits area of the Cleveland auditorium. The booth was under the direction of a committee consisting of Richard K. Gardner of Marietta College, Marietta, Ohio, chairman; Lois E. Engleman of Denison University, Granville, Ohio, and Ilo D. Fisher of Wittenberg University, Springfield, Ohio.

Volunteers who staffed the booth included Robert M. Agard of Earlham College, Mrs. Mary Amner of Kent State University, Martha L. Biggs of Lake Forest College, Paul H. Bixler of Antioch College, Bruce M. Brown of Colgate University, Thelma Bumbaugh of Hiram College, Mrs. Anne Catlin of the University of Pittsburgh, Hazel M. DeMeyer of Western Michigan University, Oliver Dunn of Purdue University, JoEllen Flagg of the Case Institute of Technology, Stephen W. Ford of the University of Michigan, Wrayton E. Gardner of St. Louis University, Ruth E. Gilley of Olivet Nazarene College, Alice M. Hall of Lafayette College, Mrs. Thelma G. Harper of Central State College, Wilberforce, Ohio; Edward C. Heintz of Kenyon College, Clyde Hordusky of the Case Institute of Technology, Chizuko Ishimatsu of the Oregon College of Education, Emerson Jacob of Baldwin-Wallace College, Merrill Jones of Michigan State University, Henry C. Koch of Michigan State University, Gertrude Linnenbruegge of Ohio University, Mrs. Helen Moffett of Western Reserve University, Warren Owens of the University of Michigan, John Reed of Ohio Wesleyan University, Dorothy W. Reeder of the State Teachers College at Towson, Maryland, Anne Schmidt of Kansas State University, Jack Scott of Western Reserve University, Helen Elizabeth Shively of Ashland College, Donald T. Smith of Boston University, Margaret K. Spangler of Pennsylvania State University, Katharine M. Stokes of Western Michigan University, Francis Strada of the Case Institute of Technology, Mrs. Clara M. Stuart of Western Reserve University, Marion E. Vosburgh of Bard College, Mrs. Ruth T. Wallace of the University of Pittsburgh, Elizabeth Windsor of Iowa State University, Herbert C. Zafren of Hebrew Union College, and Margaret L. Zenk of the University of Pittsburgh. 